\title{
KETERAMPILAN KONSELING BERBASIS METAKOGNISI
}

\author{
Carolina L. Radjah \\ Bimbingan dan Konseling-Fakultas Ilmu Pendidikan-Universitas Negeri Malang-Jl.Semarang No. 5 Malang \\ E-mail: inawasis2409@gmail.com
}

\begin{abstract}
Abstrak: Penelitian ini bertujuan mendeskripsikan karakteristik dan metakognisi konselor Sekolah Menengah Atas. Jenis penelitian yang digunakan deskriptif dengan metode survei. Subyek penelitian adalah konselor sekolah sebanyak 166 orang. Hasil penelitian menunjukkan bahwa dalam proses konseling belum sepenuhnya menerapkan keterampilan konseling berbasis metakognisi. Hal ini mengindikasikan bahwa dalam pelaksanaan konseling, konselor belum mmemperhitungkan keefektifan keterampilan intrapersonal sebagai suatu keterampilan yang terintegrasi dalam diri konselor.
\end{abstract}

Kata kunci: keterampilan konseling; metakognisi; konselor; sekolah menengah atas

Konseling merupakan sebuah pekerjaan profesional yang dalam pelayanan ahlinya tidak hanya sekadar menerapkan seperangkat prosedur tetap, melainkan selalu berpikir dengan mengerahkan kemampuan akademik yang dikuasainya untuk melakukan layanan konseling. Artinya, menjadi konselor profesional harus memenuhi standar kompetensi akademik maupun standar kompetensi profesional, sebagaimana diamanatkan dalam Peraturan Menteri Pendidikan Nasional (Permendiknas) No. 27 Tahun 2008 tentang standar Kualifikasi Akademik dan Kompetensi Konselor pada pasal 1 ayat 1).

Untuk bidang pendidikan profesional konselor, salah satu unsur utama program kurikuler adalah latihan pembentukan metakognisi konselor (Jones, 2005). Metakognisi merupakan intrapersonal skill, yaitu proses melakukan monitoring dan refleksi pikiran pada saat melakukan suatu aktivitas, seperti bagaimana dan kapan akan menggunakan prosedur spesifik untuk memecahkan masalah konseli (Jones 2005).

Ekspektasi kinerja konselor dalam melaksanakan tugas layanan konseling dilandasi oleh motif altruistik, sikap empatik, menghormati dan menghargai keragaman, serta mengutamakan kepentingan konseli di atas kepentingan yang lain. Untuk menjawab dan merealisasikan kinerja tersebut, maka metakognisi yang harus dimiliki oleh konselor, menurut Jones (2005), antara lain wicara diri positif, pengharapan yang membantu, penjelasan yang membantu, persepsi yang membantu, aturan-aturan yang membantu, dan citra visual yang membantu. Ini merupakan serangkaian keterampilan dan tindakan yang harus dimiliki oleh seorang konselor profesional agar konseling yang dilakukan dapat berlangsung secara tepat dan efektif. Dengan keterampilan yang dimiliki tersebut, seorang konselor dapat meninjau kembali tindakan-tindakan yang telah diambil dan melakukan penyesuaian ada tindakan berikutnya. Setelah itu berlangsung, yang tersimpan dalam kognisi konselor yang bersangkutan merupakan pengalaman atau pengetahuan tentang cara mempersepsikan dan menangani masalah konseli dalam proses konseling. 
Sebagai kegiatan profesional, tugas konselor tidak saja melaksanakan program sesuai prosedur tetap, namun juga melaksanakan pertimbangan- pertimbangan yang sebaik-baiknya terhadap setiap tindakan yang diambil dalam memfasilitasi perkembangan pribadi konseli. Selain itu, konselor profesional dituntut untuk selalu mengkritisi tindakan profesionalnya dalam artian berpikir secara kritis tentang tindakannya, pengalamannya, keputusan-keputusan yang diambil selama pelaksanaan konseling. Hal itu dilakukan, karena tugas konselor berada dalam kawasan pelayanan yang bertujuan mengembangkan potensi dan memandirikan konseli dalam pengambilan keputusan. Untuk itu, ekspektasi kinerja konselor harus senantiasa memiliki standar kerja tinggi yang berorientasi pada kualitas yang oleh Joyce dan Weil (2009) dinamakan principle of reaction, yaitu hadirnya motif altruistik dalam sikap dan falsafah kerja, sikap melayani secara tulus dan rendah hati, kreativitas kerja yang lahir dari penghayatan atas bidang profesinya, dan kesetiaan pada kode etik profesi.

Secara konseptual dapat dimaknai bahwa layanan konseling selalu harus merupakan pengimplementasian seni yang bertumpu pada landasan akademik yang handal.

\section{METODE}

Penelitian ini menggunakan jenis penelitian deskriptif yang dilakukan dengan metode survei. Survei bertujuan untuk memperoleh data tentang karakteristik dan meta kognisi konselor dalam pelaksanaan konseling. Subjek penelitian pada penelitian survei terdiri atas konselor lima kota Jawa Timur: Malang, Surabaya, Kediri, Pamekasan, Jember sejumlah 166 orang konselor. Instrumen untuk mengukur variabel penelitian disusun sendiri oleh peneliti berdasarkan variabel yang dijabarkan ke dalam indikatorindikator penelitian. Data yang diperoleh dianalisis menggunakan statistik deskriptif.

\section{HASIL}

Pelaksanaan konseling yang dilakukan konselor sekolah menengah atas, terutama terkait dengan penerapan keterampilan konseling berbasis metakognisi disekolah terdapat keragaman dalam melakukan masing-masing komponen, ada konselor yang menerapkan empat dari enam indikator metakognisi yaitu, penciptaan peraturan, penciptaan persepsi, penciptaan self talk dan penciptaan penjelasan. Dua indikator yang tidak diterapkan konselor ini meliputi penciptaan citra visual dan penciptaan pengharapan. Kemudian ditemukan pula konselor yang menerapkan empat indikator metakognisi dalam proses konseling yang meliputi, penciptaan peraturan, penciptaan citra visual, penciptaan penjelasan dan penciptaan pengharapan. Dua indikator metakognisi lainnya yang tidak diterapkan konselor ini meliputi penciptaan persepsi dan penciptaan self talk. Temuan berikutnya ada konselor yang menerapkan lima di antara enam indikator metakognisi yang ada yaitu menciptakan peraturan, menciptakan persepsi, menciptakan self talk, menciptakan citra visual, dan menciptakan pengharapan. Indikator yang tidak digunakan konselor ini dalam proses konseling yaitu penciptaan penjelasan; Berikutnya konselor menerapkan penciptaan peraturan, penciptaan persepsi, penciptaan citra visual, penciptaan penjelasan, dan penciptaan pengharapan. Satu-satunya indikator metakognisi yang tidak digunakan konselor ini dalam proses konseling adalah penciptaan self talk. Berikutnya lagi ditemukan pula konselor yang menerapkan lima indikator matakognisi masing-masing, penciptaan peraturan, penciptaan persepsi, penciptaan self talk, penciptaan citra visual, dan penciptaan penjelasan, sedangkan penciptaan pengharapan belum diterapkan konselor ini dalam proses konseling. Konselor berikutnya menerapkan semua indikator yang ada yaitu, penciptaan peraturan, penciptaan persepsi, penciptaan self talk, penciptaan citra visual, penciptaan penjelasan, serta penciptaan pengharapan. 


\section{PEMBAHASAN}

Menurut Lin (2001), Susan (2002) penciptaan peraturan dalam proses konseling juga dimaksudkan agar konselor dan konseli tetap konsisten terhadap aturan-aturan dasar yang dibutuhkan dalam suatu proses konseling. Li Cao dan Nietfeld (2007) penciptaan peraturan terkait juga dengan desain proses konseling yang diinginkan. Desain proses yang dimaksud Li Cao dan Nietfield berkaitan erat dengan aktifitas mengidetifikasi masalah dan penetapan prosedur yang dipandang relevan dalam sebuah proses konseling.

Pandangan Lin (2001), Susan (2002) serta Licao dan Nietfeld (2007) memperkuat temuan penelitian ini terkait dengan penciptaan peraturan sebagai langkah awal dalam proses konseling. Perbedaan utama temuan penelitian ini dengan pandangan para ahli tersebut terletak pada konteks konseling di Indonesia. Dalam perspektif konseling di Indonesia, penciptaan peraturan juga dimaksudkan sebagai sebuah prosedur standar yang diperlukan dalam profesi bimbingan konseling. Perbedaan temuan penelitian ini dengan pendapat para ahli tersebut dapat dipahami sebab profesi bimbingan dan konseling di Indonesia memiliki landasan kode etik tersendiri yang memberikan kontribusi terhadap sebuah tindak konseling yang dipilih oleh konselor.

Secara teoretik menciptakan peraturan yang dapat membantu adalah peraturan-peraturan yang realistis dan preferensial, menggantikan peraturan-peraturan yang demanding atau absolute (Ellis, 2005). Peraturan realistik preferensial bersifat luwes dan memberikan alternatif pilihan, jauh dari tuntutan yang tidak rasional. Sedangkan peraturan yang demanding atau absolutistic bersifat kaku, mutlak, dan tidak memberikan pilihan karena sifatnya yang dogmatis.

Temuan penelitian menunjukkan bahwa peraturan yang diciptakan oleh konselor lebih mengacu pada peraturan yang realistik dan preferensial. Hal ini dapat dimengerti, sebab konstruksi pikiran yang melatarbelakangi aturan ini dikaitkan dengan client yang bermasalah, sehingga penggunaan peraturan yang realistik dan preferensial akan lebih mudah bagi konselor untuk menciptakan relasi dan tindakan konseling yang lebih realistis. Penciptaan persepsi konselor dalam proses konseling yang ditemukan dalam penelitian ini berorientasi pada upaya menumbuhkan sikap positif, bahwa setiap masalah yang dihadapi siswa pasti ada jalan keluarnya. Persepsi semacam ini lahir dari optimisme konselor agar dapat memberikan bantukan kepada client agar dapat memecahkan masalah yang dihadapinya. Persepsi yang positif melahirkan sikap yang positif bahwa siswa yang sedang dihadapi merupakan subyek yang utuh dan memiliki kedudukan yang setara dengan siswa lainnya.

Penciptaan self talk dalam proses konseling dimaksudkan agar konselor sendiri dapat belajar dari masalah siswa, melakukan evaluasi dan kilas balik yang dilakukan di sekolah maupun setelah berada di rumah. Beberapa konselor juga melakukan perenungan diri ini dengan cara mendoakan siswa yang bermasalah, agar diberi kemudahan dalam mengatasi masalah yang dihadapi. Tindakan ini dilakukan konselor pada sekolah-sekolah yang memiliki afiliasi keagamaan tertentu. Fakta menarik lainnya terkait dengan self talk ini, adalah adanya keterkaitan nilai-nilai religius yang dianut oleh konselor dengan self talk yang diciptakannya. Beberapa konselor selalu mendoakan konseli pada akhir sesi konseling agar masalah yang dihadapinya tidak menjadi beban dalam hidup konseli. Ini menunjukkan bahwa terdapat kaitan yang erat antara self talk yang diciptakan dengan pengharapan bagi pemecahan masalah konseli di masa yang akan datang.

Temuan penelitian menyangkut self talk ini membuktikan bahwa tindakan konselor tidak saja dipengaruhi oleh pengalaman akademik, profesi, pribadi dan persepsi konselor terhadap siswa, tetapi juga dipengaruhi oleh latar belakang pengalaman religiusnya.

Terkait dengan temuan penelitian ini, penciptaan self talk yang dilakukan konselor sebagai bentuk refleksi diri terhadap pengakuan akan adanya kekuatan transendental yang melampaui kekuatan diri konselor. Kesadaran konselor akan kekuatan ini menjadikannya lebih percaya bahwa, masalah yang dihadapi siswa akan menemukan jalan keluarnya jika ia memohon pertolongan Tuhan yang di imaninya.

Temuan penelitian menunjukkan bahwa kecenderungan penciptaan citra visual konselor lebih terarah pada upaya membangun persahabatan dengan konseli, sehingga tercipta kondisi yang menenangkan dan menyenangkan. Bagi beberapa konselor, citra visual ini ditampilkan dalam bentuk 
penataan ruang konseling yang nyaman, sehingga memungkinkan konseli betah selama proses konseling. Penciptaan citra visual sebagaimana yang ditemukan dalam penelitian ini, dapat dipahami sebab ketika individu mengalami suatu perasaan, atau sensasi yang berarti (baik positif maupun negatif), maka ia cenderung berpikir dalam image (Lazarus, 2005). Faktor penting yang memengaruhi, penciptaan citra visual yang positif adalah self conciousness individu dalam relasinya dengan orang lain. Ketika individu memiliki self conciousness bahwa ia merupakan bagian dari orang lain, maka citra visual yang ditampilkannya lebih positif dari pada citra visual yang terbangun karena adanya prasangka (Jones, 2005)

Penciptaan penjelasan sebagai salah satu dimensi penting dalam proses konseling, dilakukan konselor dengan maksud untuk memberikan pemahaman terhadap masalah yang dihadapi siswa serta untuk mendorong keberaniannya mengungkapkan masalah yang dihadapi secara jujur dan terbuka. Yang menarik dari temuan ini adalah, konselor menggunakan dirinya sebagai contoh dalam memberikan penjelasan. Dari temuan penelitian yang ada, konselor menyadari bahwa diri mereka adalah manusia biasa yang juga dapat berbuat kesalahan. Contoh penjelasan seperti ini menarik, karena tidak melibatkan alasan yang dibuat-buat atau alasan yang terlalu berlebihan. Menurut Jones (2005) penjelasan seperti ini lebih bersifat netral dan sangat realistis sehingga akan membantu konseli agar lebih mudah mengungkapkan masalah yang dihadapi serta menimbulkan harapan yang lebih besar bagi penyelesaiannya.

Keenam, ditemukan bahwa penciptaan pengharapan, dilakukan konselor melalui pemberian motivasi, membangun kesadaran dan kepercayaan diri, menawarkan solusi, serta memberikan kesempatan kepada siswa untuk bertemu lagi, apabila permasalahan yang dialaminya belum terpecahkan.

Pengharapan yang diciptakan konselor menurut Jones (2005) dan Ellis (2003) merupakan dimensi metakognisi yang paling dibutuhkan dalam proses dan tindakan konseling. Melalui penciptaan pengharapan, konseli memperolah 'keyakinan' dan semangat untuk dapat memecahkan masalah yang dihadapi. Perlunya penciptaan pengharapan dalam konseling menurut Friedli (2007) memiliki kontribusi terhadap pemulihan kesehatan mental client. Pandangan ini menunjukkan bahwa penciptaan pengharapan tidak sekadar berorientasi pada pemecahan masalah jangka pendek tetapi juga untuk melakukan pemulihan kesehatan mental. Terkait dengan hal tersebut di atas, beberapa pakar seperti Williams, C. R., \& Butler, S. K. (2010) serta Bowers, Minichiello, Plummer (2007) berpendapat bahwa, penciptaan pengharapan yang direncanakan secara baik akan jauh lebih baik dan memberikan dampak positif kearah pemecahan masalah konseli. Pentingnya penciptaan dalam proses konseling seperti yang telah dilakukan, sebenarnya bukan hal yang baru. Dalam kegiatan konseling yang dilakukan pada lembega-lembaga keagamaan penciptaan pengharapan dalam konseling menjadi inti semua aktifitas konseling, sehingga memunculkan konsep konseling berpengharapan. Konseling pengharapan juga bersumber dari nilai-nilai religius yang diyakini oleh konseli yang memungkinkannya mengantungkan harapan penyelesaian masalah yang dihadapi (Johnson, 2007; Kellemen, 2010).

\section{SIMPULAN}

\section{Simpulan}

Sebagian besar konselor berpendidikan sarjana satu dengan masa kerja di atas sepuluh tahun, usia konselor berkisar diatas empat puluh tahun, menangani siswa rata rata diatas seratus orang siswa. Sebagian besar sekalah sudah memiliki konselor dengan dilengkapi fasilitas ruang khusus untuk konseling dan sebagian besar proses kedatangan siswa atas inisiatif siswa sendiri.

Deskripsi metakognisi konselor di Sekolah Menengah Atas dalam proses konseling meliputi: penciptaan peraturan, penciptaan persepsi, penciptaan self talk, penciptaan citra visual, penciptaan penjelasan dan penciptaan pengharapan. Alasan yang mendasari pemilihan berbagai keterampilan metakognisi ini mengacu pada aktifitas profesional dimana keterampilan-keterampilan ini dipandang sebagai keterampilan utama yang dibutuhkan untuk mencapai tujuan konseling. 
94 | Jurnal Kajian Bimbingan dan Konseling Vol. 1, No. 3, 2016, hlm.90—94

\section{Saran}

Berdasarkan kesimpulan penelitian tersebut di atas, saran lebih lanjut kegiatan penelitian ini adalah mengembangkan model pelatihan konselor berbasis metakognisi. Model pelatihan konselor berbasis metakognisi yang perlu dikembangkan adalah sebagai berikut: Model Pelatihan Konselor berbasis Metakognisi terdiri atas tujuan, kurikulum, strategi; pelaksanaan, dan evaluasi; Bahan Pelatihan Cetak (buku teks) Model Pelatihan; Bahan Pelatihan cetak (buku teks) Metakognisi dalam Konseling; Bahan Pelatihan Audio dalam bentuk MP3 yang dapat dimuat di komputer, MP3 Player, telepon genggam, dan WEB; Bahan Pelatihan Video; Bahan Pelatihan komputer (multi media interaktif); dan WEB pembelajaran dengan kata kunci pelatihan, metakognisi, konselor

\section{DAFTAR RUJUKAN}

Departemen Pendidikan Nasional, Permendiknas No. 27 Tahun 2008 tentang standar Kompetensi Konselor.

Flavell, J.H. 1992. Metacognition and Cognitive Monitoeing: A New Area of Cognitive-Developmental Inquiry. Dalam Nelson, T.O. (Ed). Metacognition: Core Readings_(hlm. 3-8). Boston: Allyn and Bacon.

Joyce, B, Weil, M dan Calhoun, E. 2009. Models of Teaching (Eight Edition). Upper Saddle River, New Jersey, USA.

Marzano, R.J; Brand, R.S; Hughes, C.S; Jones, B.F: Presseisen, B.Z; Ranking, S.C. dan Suhor, Chales. 1988. Dimensions of Thingking: A Framework for Curiculum and Instrustions. Alexandria: ASCD.

Metealfe,J 2009. Metacognitive judgments and control of study. Columbia University, Vol 18Number 3

Jones, R. 2003. Basic Counseling Skills: A Helper's Manual. London: Sage Publications.

Newell, A. dan Simon, H.A. 1972. Human Problem Solving. New York: Prentice-Hall.

Joni, R. T. 2008. Penataan Pendidikan Profesional Konselor. Profesional Dosen, Pra- jabatan. Makalah disajikan dalam KONASPI, Psikoterapis se - Asia Pasifik, tanggal 5- 7 April 2008, di Jakarta.

Joni, T. 2009. Recognition Prior Learning. Makalah. Jakarta: Ditjen PMPTK.

Schone, DA. 1983. The Reflective Practitioner: How Profesionals Think in Action. New York: Basic Book Inc., Publishers

Shulman, L.S. 1987. Knowledge and Teaching: Foundations of New Reform. Harvard Educational review L VII:12

Veenman Marcel V. J., Van Hout-Wolters, Bernadette H. A. M., Afflerbach, Peter. 2006. Metacognition and learning: conceptual and methodological considerations. Metacognition Learning. 2006. Vol. 1, pp. 3-14.

Williams, C. R., \& Butler, S. K. (2010). A new retention variable: Hope and first generation college students. Sumber: di undah dari http://counselingoutfitters.com/vistas/ vistas10/ Article_11.pdf. tanggal 10 Januaei 2011

Wulf, C.1998. Intercultural Education. Education, Volume 58, halaman 7- 19. Tubigen: Institute for Scientific Cooperation. 